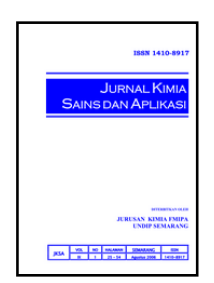

\title{
Isolasi dan Karakterisasi Kitinase dari Isolat Jamur Akuatik Kitinolitik berasal dari Kupu-kupu (Lepidoptera)
}

\author{
Reny Ingemer Selvia ${ }^{a}$, Wuryanti ${ }^{\mathrm{a}^{*}}$, Sriatun $^{\mathrm{a}}$ \\ a Biochemistry Laboratory, Chemistry Department, Faculty of Sciences and Mathematics, Diponegoro University, Jalan Prof. \\ Soedarto, Tembalang, Semarang \\ * Corresponding author: wuryanti@live.undip.ac.id
}

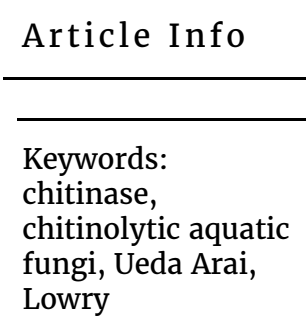

\begin{abstract}
Research on the isolation and characterization of chitinase from the chitinolytic aquatic fungi isolate derived from butterfly (Lepidoptera) has been done. This study aimed to obtain chitinase from chitinolytic aquatic fungi isolate derived from butterfly (Lepidoptera), data of the chitinase specific activity and chitinase optimum conditions include $\mathrm{pH}$ and temperature. Chitinase activity assays in this study performed with the method of Ueda Arai, while the protein concentration measurements performed with Lowry method. The specific activity in this study was obtained from the ratio between units of chitinase activity by protein content. The highest specific activity of chitinase in this study is shown by the fraction 3 is 51.17 units/mg protein. The results from the characterization of chitinase shows that $\mathrm{pH} 3.8$ and a temperature 0 $40.5^{\circ} \mathrm{C}$ is the optimum condition of chitinase.
\end{abstract}

\section{Abstrak}

Kata Kunci:

kitinase, jamur akuatik kitinolitik, Ueda Arai, Lowry
Telah dilakukan penelitian tentang isolasi dan karakterisasi kitinase dari isolat jamur akuatik kitinolitik berasal dari kupu-kupu (Lepidoptera). Penelitian ini bertujuan untuk memperoleh kitinase dan data aktivitas spesifik kitinase dari isolat jamur akuatik kitinolitik yang berasal dari kupu-kupu serta memperoleh data kondisi optimum kitinase meliputi pH dan suhu. Pengujian aktivitas kitinase pada penelitian ini dilakukan dengan metode Ueda Arai, sedangkan pengukuran kadar protein dilakukan dengan metode Lowry. Aktivitas spesifik pada penelitian ini diperoleh dari rasio antara unit aktivitas dengan kadar protein kitinase. Aktivitas spesifik tertinggi kitinase pada penelitian ini ditunjukkan oleh fraksi 3 yaitu sebesar 51,17 unit/mg protein. Hasil karakterisasi kitinase menunjukkan bahwa $\mathrm{pH} 3,8$ dan suhu $40,5^{\circ} \mathrm{C}$ merupakan kondisi optimum kitinase.

\section{Pendahuluan}

Kitinase merupakan suatu enzim glikosil hidrolase yang mengkatalisis degradasi kitin yaitu senyawa polimer dari $\mathrm{N}$-asetilglukosamin yang membentuk ikatan linier $\beta-1,4$ [1]. Enzim ini ditemukan dalam berbagai mikroorganisme yang termasuk dalam jenis jamur dan bakteri. Salah satu jenis jamur penghasil kitinase adalah jamur akuatik kitinolitik. Jamur akuatik kitinolitik merupakan jamur yang memiliki habitat di air, baik di permukaan maupun di dalam air, dan menghidrolisis kitin dengan mensekresikan kitinase [2].
Jamur akuatik kitinolitik dapat berperan sebagai dekomposer serangga yang telah mati dengan cara menghidrolisis tubuh serangga yang tersusun atas kitin sehingga menghasilkan senyawa-senyawa yang lebih sederhana seperti karbon dan nitrogen. Kupu-kupu merupakan salah satu jenis serangga yang termasuk dalam ordo lepidoptera. Kupu-kupu memiliki ciri bentuk dewasanya mempunyai dua pasang sayap yang ditutupi dengan bulu-bulu atau sisik. Tubuh kupu-kupu terbagi atas tiga bagian, yaitu kepala, toraks, dan 
abdomen yang dilapisi oleh eksoskeleton yang terdiri dari lapisan kitin [3].

Aplikasi kitinase pada bidang pertanian dan perkebunan sangat potensial karena dapat dimanfaatkan sebagai agen biokontrol terutama bagi tanaman yang terserang infeksi jamur. Hal ini dikarenakan kitin yang merupakan komponen utama dinding sel jamur dapat didegradasi kitinase menghasilkan produk yang ramah lingkungan dibandingkan penggunaan zat kimia. Kitinase dari organisme laut berperan dalam proses daur ulang kitin. Banyak bakteri dan jamur mengeluarkan kitinase untuk menguraikan kitin menjadi karbon dan nitrogen. Dua senyawa terakhir ini selanjutnya dipakai sebagai sumber energi biota lainnya Dengan adanya kitinase penguraian kitin berlangsung kontinyu sehingga tidak terjadi akumulasi kitin dari sisa cangkang udang, kepiting, cumi dan organisme laut lainnya. Produk hasil hidrolisis senyawa kitin juga banyak manfaat di bidang pertanian dan industri makanan. Senyawa oligo-kitin telah dilaporkan dapat membantu meningkatkan sistem kekebalan di dalam tubuh, memiliki sifat anti bakteri dan anti kapang, serta meningkatkan daya tahan pada tanaman sedangkan monomernya, yaitu Nasetilglukosamin dapat digunakan sebagai obat untuk mengontrol kadar gula dalam darah. Untuk kosmetik, senyawa gula ini dapat membantu mengurangi hilangnya hiperpigmentasi, karena N-asetil-Dglukosamin dapat membantu mengurangi aktivitas enzim tirosinase yang berperan dalam produksi melanin [1].

Kitinase yang diisolasi dari jamur yang berbeda akan memiliki aktivitas tertinggi pada $\mathrm{pH}$ dan suhu yang berbeda. Karakterisasi dilakukan berdasarkan $\mathrm{pH}$ dan suhu karena kedua parameter tersebut berperan langsung pada aktivitas enzim. Jika lingkungan suatu enzim memiliki pH dan suhu optimum maka aktivitas enzim yang dihasilkan pun akan maksimum.

Oleh karena itu, pada penelitian ini dilakukan isolasi kitinase dari isolat jamur akuatik kitinolitik yang berasal dari kupu-kupu dan kemudian dilakukan pula karakterisasi kitinase yang dihasilkan meliputi $\mathrm{pH}$ dan suhu.

\section{Metode Penelitian}

\section{Alat dan Bahan}

Peralatan gelas laboratorium, lampu spirtus, autoklaf, shaker, mikropipet, alumunium foil, spektrofotometer UV-VIS, sentrifus, membran selofan, pengaduk magnet, botol vial, neraca analitik, oven, kompor listrik, kertas saring, kapas, kain kasa, benang kasur. Biakan murni jamur akuatik kitinolitik, aquades, media kitin padat, media kitin cair, buffer asetat 0,05M pH 5, amonium sulfat, $\mathrm{BaCl}_{2}$, EDTA Alkali, BSA, kalium natrium tartrat, $\mathrm{CuSO}_{4}$, dan folin-ciocalteau

\section{Produksi Kitinase}

Isolat jamur akuatik kitinolitik hasil peremajaan dipindahkan secara aseptik ke dalam media fermentasi dengan volume media fermentasi $500 \mathrm{~mL}$ sebagai kultur produksi. Media fermentasi ini diinkubasi pada inkubator shaker selama 3 hari. Media fermentasi hasil inkubasi tersebut disaring menggunakan kertas saring lalu disentrifugasi dengan kecepatan 5000 rpm selama 20 menit. Filtrat yang didapatkan merupakan ekstrak kasar enzim.

\section{Fraksinasi dan Dialisis}

Tingkat kejenuhan amonium sulfat dikelompokkan menjadi fraksi I, $20-40 \%$ fraksi II, $40-60 \%$ fraksi III, $60-80 \%$ fraksi IV, $80-100 \%$ fraksi V. Tahap fraksinasi dimulai dengan menambahkan amonium sulfat pada larutan ekstrak kasar enzim sambil diaduk menggunakan pengaduk magnet kemudian larutan didiamkan satu malam. Selanjutnya disentrifugasi pada suhu $4^{\circ} \mathrm{C}$ dengan kecepatan $5000 \mathrm{rpm}$ selama 20 menit. Filtrat dan endapan akan terpisah setelah disentrifugasi. Filtrat yang diperoleh dilanjutkan untuk fraksinasi selanjutnya, sedangkan endapan disuspensikan dalam bufer asetat $0,05 \mathrm{M} \mathrm{pH} 5$.

Hasil fraksinasi kemudian didialisis dengan merendam kantong selofan yang berisi enzim dalam bufer asetat 0,00005 $\mathrm{M}$ dan diaduk menggunakan pengaduk magnet. Setiap dua jam bufer diganti serta diuji kandungan amonium sulfatnya dengan $\mathrm{BaCl}_{2}$. Proses dialisis dihentikan sampai dengan bebas sulfat.

\section{Penentuan Aktivitas Kitinase}

Penentuan aktivitas kitinase dilakukan dengan metode Veda dan Arai [4]. Sebanyak $1 \mathrm{~mL}$ koloidal kitin 0,3\%, $2 \mathrm{~mL}$ bufer asetat $0,05 \mathrm{M} \mathrm{pH} 5$ dan $1 \mathrm{~mL}$ filtrat enzim dimasukkan ke dalam tabung reaksi dan diinkubasi pada suhu $40^{\circ} \mathrm{C}$ selama 1,5 jam. Larutan kemudian diukur serapannya pada panjang gelombang $660 \mathrm{~nm}$ menggunakan spektrofotometer UV-VIS.

\section{Pengukuran Kadar Protein}

Sebanyak 0,5 mL enzim ditambah dengan 2,5 mL lowry $\mathrm{C}$ dikocok perlahan kemudian diinkubasi pada suhu kamar selama 10 menit. Selanjutnya ditambahkan 0,25 mL lowry D dan segera dikocok lalu diinkubasi pada suhu kamar selama 30 menit. Larutan tersebut kemudian diukur absorbansinya pada panjang gelombang maksimum, yaitu $695 \mathrm{~nm}$ dengan menggunakan spektrofotometer UV-VIS.

\section{Karakterisasi pH Optimum Kitinase}

Sebanyak $1 \mathrm{~mL}$ koloidal kitin 0,3\% yang dilarutkan dalam bufer asetat dengan variasi $\mathrm{pH} 3,6 ; 3,8 ; 4 ; 4,2$; dan 4,4 ditambah $2 \mathrm{~mL}$ bufer asetat dengan variasi $\mathrm{pH}$ yang sama lalu ditambah $1 \mathrm{~mL}$ filtrat enzim dimasukkan ke dalam tabung reaksi dan diinkubasi pada suhu $40^{\circ} \mathrm{C}$ selama 1,5 jam. Larutan kemudian diukur serapannya pada panjang gelombang $660 \mathrm{~nm}$ menggunakan spektrofotometer UV-VIS.

\section{Karakterisasi Suhu Optimum Kitinase}

Sebanyak $1 \mathrm{~mL}$ koloidal kitin $0,3 \%$ yang dilarutkan dalam bufer asetat dengan variasi $\mathrm{pH}$ 3,6 ; 3,8 ; 4 4,2 ; 4,4, ditambah $2 \mathrm{~mL}$ bufer asetat dengan variasi $\mathrm{pH}$ yang sama lalu ditambah $1 \mathrm{~mL}$ filtrat enzim hasil karakterisasi $\mathrm{pH}$ optimum dimasukkan ke dalam tabung 
reaksi dan diinkubasi pada suhu $40^{\circ} \mathrm{C}$ selama 1,5 jam. Larutan kemudian diukur serapannya pada panjang gelombang $660 \mathrm{~nm}$ menggunakan spektrofotometer UVVIS.

\section{Hasil dan Pembahasan}

\section{Produksi Kitinase}

Produksi kitinase dari jamur akuatik kitinolitik memerlukan nutrien dasar yang terdiri dari sumber karbon, nitrogen, dan faktor esensial pertumbuhan (mineral dan vitamin) untuk tumbuh, oleh karena itu untuk mendapatkan hasil yang maksimum, media pertumbuhan yang digunakan harus mengandung nutrien dasar. Media produksi enzim yang digunakan terdiri atas koloid kitin $1 \%$, yeast ekstrak $0,25 \%$, pepton $0,25 \%, \mathrm{NaNO}_{3} \mathrm{0}, 2 \%, \mathrm{KH}_{2} \mathrm{PO}_{4} 0,1 \%, \mathrm{MgSO}_{4} \cdot 7 \mathrm{H}_{2} \mathrm{O} 0,05 \%$, $\mathrm{KCl} 0,05 \%$, dan $\mathrm{FeSO}_{4}$ 0,01\%. Isolat jamur akuatik kitinolitik ditumbuhkan sampai waktu eksponensialnya, yaitu 72 jam atau 3 hari. Hal ini sesuai dengan data kurva pertumbuhan dimana jamur akuatik kitinolitik mencapai puncak fase eksponensial pada jam ke 72 . Pemanenan yang dilakukan pada waktu yang terlalu singkat akan menghasilkan enzim yang sedikit karena mikroba belum beradaptasi dengan lingkungannya [5]. Jumlah mikroba yang semakin meningkat dari hari ke hari akan membutuhkan nutrien yang semakin banyak. Nutrien yang berbentuk polimer tidak dapat memasuki sel mikroba secara langsung. Polimer ini akan dicerna terlebih dahulu oleh enzim-enzim ekstraseluler yang disekresikan oleh mikroba [6]. Produksi enzim-enzim mikrobial memanfaatkan kitin sebagai substrat untuk menghasilkan enzim kitinase.

Produksi kitinase setelah 72 jam dilanjutkan disentrifugasi untuk memisahkan media yang mengandung kitinase dengan sel jamur akuatik kitinolitik sehingga dihasilkan filtrat yang berisi ekstrak kasar enzim dan terpisah dari sel jamur serta sisa-sisa media yang tidak larut. Proses sentrifugasi dilakukan pada suhu $4^{\circ} \mathrm{C}$ selama 20 menit dengan kecepatan 5000 rpm.

\section{Fraksinasi dan Dialisis}

Pemurnian protein dengan menggunakan amonium sulfat merupakan salah satu metode pemurnian awal pada enzim. Pemilihan amonium sulfat didasarkan pada tingkat kelarutan garam amonium sulfat yang besar sehingga mudah berinteraksi dengan molekul air [7]. Filtrat hasil sentrifugasi yang berupa ekstrak kasar kitinase yang bebas sel untuk selanjutnya disebut EK, diendapkan dengan amonium sulfat. Pengendapan kitinase dilakukan dengan variasi tingkat kejenuhan amonium sulfat yaitu 0-20\% (Fraksi 1), 20-40\% (Fraksi 2), 40-60\% (Fraksi 3), 60-80\% (Fraksi 4), 80-100\% (Fraksi 5). Pengendapan dengan garam menggunakan prinsip salting out. Kelarutan protein akan berkurang pada konsentrasi garam yang tinggi. Konsentrasi garam yang meningkat mengakibatkan air akan lepas dari protein yang menyebabkan terjadinya penempelan ikatan hidrofobik dari satu protein dengan protein yang lain dan menghasilkan endapan [8]. Peristiwa pemisahan protein ini disebut salting out.
Penambahan garam dilakukan secara perlahan pada suhu dingin sambil dilakukan pengadukan. Pengkondisian pada suhu dingin dilakukan karena terjadi peningkatan suhu akibat proses pelarutan yang dibantu dengan magnetic stirrer. Hal ini dapat dilakukan dengan mengkondisikan larutan dalam air yang dicampur es. Pengendapan protein disetimbangkan dengan cara supernatan enzim yang bebas sel yang telah ditambahkan dengan amonium sulfat didiamkan selama semalam. Selama proses ini molekul protein akan beragregasi, tetapi tidak semuanya akan langsung mengendap. Pemisahan supernatan dan endapan protein dilakukan dengan sentrifugasi. Endapan tersebut dilakukan dalam bufer asetat 0,05 $\mathrm{M} \mathrm{pH} 5$.

Dialisis dalam penelitian ini merupakan proses yang dilakukan untuk memisahkan atau menghilangkan molekul garam amonium sulfat dan ion-ion pengganggu lainnya yang berpengaruh terhadap kestabilan molekul protein enzim selama penyimpanan, dimana molekul-molekul kecil dan ion-ion akan melewati pori-pori selaput semipermiabel dan keluar dari kantong selofan. Menurut Rachmadani [5], untuk menghindari kontaminan dari bahan logam, maka kantung dialisis terlebih dahulu direbus selama 10 menit dalam larutan EDTA alkali lalu dicuci dan direbus kembali dengan air bebas ion selama 10 menit sebanyak 2 kali. Dialisis dilakukan di lingkungan yang dingin untuk mengurangi terjadinya penurunan aktivitas enzim. Pengadukan dengan kecepatan rendah bertujuan untuk mempermudah keluarnya molekul berukuran kecil dari kantung dialisis dan mencegah molekul tersebut terkonsentrasi di sekitar kantung. Pada proses dialisis keberadaan amonium sulfat diharapkan sudah tidak ada karena amonium sulfat akan mengganggu kerja enzim. Keberadaan amonium sulfat di dalam kantong dialisis diuji dengan menambahkan $\mathrm{BaCl}_{2}$ ke dalam larutan bufer yang berada di luar kantung dialisis.

\section{Penentuan Aktivitas Kitinase}

Kitinase bekerja mengkatalisis hidrolisis kitin menjadi monomer N-Asetilglukosamin [9]. Pada penelitian ini, aktivitas kitinase diukur dengan metode Veda dan Arai [4] berdasarkan pengurangan substrat dengan mengukur tingkat kekeruhan substrat yang telah bereaksi dengan kitinase dan diukur pada panjang gelombang $660 \mathrm{~nm}$. Satu unit aktivitas enzim didefinisikan sebagai jumlah enzim yang menyebabkan pengurangan absorbansi sebesar 0,001 campuran reaksi per menit.

\section{Pengukuran Kadar Protein}

Kadar protein pada tiap-tiap fraksi diukur dengan menggunakan metode Lowry dkk. [10]. Analisa kuantitatif pada metode ini dilakukan dalam 3 tahapan. Pertama menentukan panjang gelombang maksimum $B S A$ yang pada penelitian ini didapatkan $695 \mathrm{~nm}$ sebagai panjang gelombang maksimumnya. Kedua, pembuatan kurva standar BSA untuk mengetahui konsentrasi dan absorbansi dari protein standar, sehingga bila absorbansi sampel diketahui, maka kadar sampel dapat dihitung dengan cara mensubstitusikan ke persamaan 
kurva standar $\mathrm{Y}=\mathrm{ax}+\mathrm{b}$. Ketiga merupakan tahap pengukuran kadar protein kitinase.

Melalui metode ini, protein dalam kitinase akan bereaksi dengan $\mathrm{Cu}$ dalam larutan alkalis membentuk kompleks ion tembaga dengan ikata amida. Warna biru menjadi semakin pekat setelah bereaksi dengan reagen folin ciocalteau karena terjadi reduksi fosfotungstat dan fosfomolibdat yang berwarna kuning oleh tirosin dan triptofan yang ada dalam protein menjadi molybdenum biru dan tungsten biru [10].

\section{Pengukuran Aktivitas Spesifik Kitinase}

Aktivitas spesifik kitinase dapat dihitung dari unit aktivitas enzim per mg protein. Fraksi dengan nilai aktivitas spesifik tertinggi merupakan fraksi dengan jumlah enzim paling banyak dibandingkan fraksi lain, sehingga kemungkinan menemukan enzim lebih besar dimana aktivitas spesifik merupakan rasio antara unit aktivitas enzim dengan total protein dalam miligram. Dengan demikian, aktivitas spesifik menggambarkan tingkat kemurnian suatu enzim. Berikut adalah kurva masing-masing fraksi dengan nilai aktivitas spesifiknya

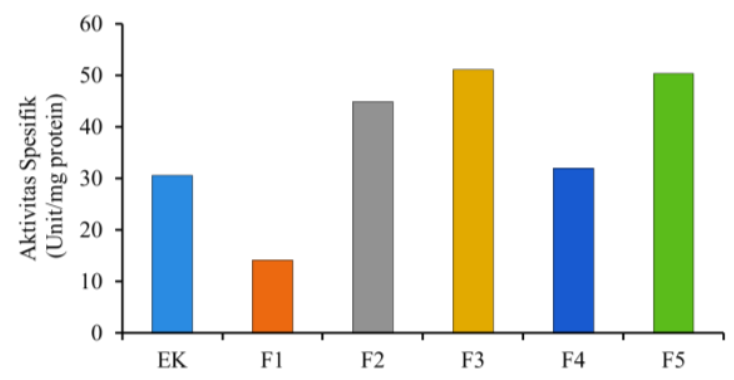

Gambar 1. Aktivitas spesifik kitinase tiap fraksi

Berdasarkan gambar 1 fraksi 3 (40-60\%) memiliki aktivitas spesifik enzim tertinggi sebesar 51,17 Unit/mg protein. Hal ini mengindikasikan bahwa pada fraksi tersebut keberadaan protein enzim paling banyak dibandingkan dengan fraksi lain, sehingga fraksi ini dapat dikatakan sebagai fraksi yang paling murni dalam kelompok fraksinasi amonium sulfat.

\section{Karakterisasi pH Optimum Kitinase}

Setiap enzim mempunyai $\mathrm{pH}$ optimum yaitu kisaran $\mathrm{pH}$ dimana enzim menunjukkan aktivitas maksimum dengan stabilitas yang tinggi. Mikroba yang hidup di alam tersebar luas mulai yang hidup di daerah asam sampai dengan alkali, dari suhu rendah sampai suhu tinggi [11]. Menurut Palmer [12] setiap enzim mempunyai karakteristik $\mathrm{pH}$ optimum dan enzim tersebut aktif pada kisaran $\mathrm{pH}$ yang relatif sempit. Penentuan $\mathrm{pH}$ optimum bertujuan untuk mengetahui kondisi optimum aktivitas enzim sehingga penggunaan enzim dapat disesuaikan dengan karakteristiknya tersebut sehingga pada saat digunakan dapat diperoleh aktivitas enzim yang maksimal.

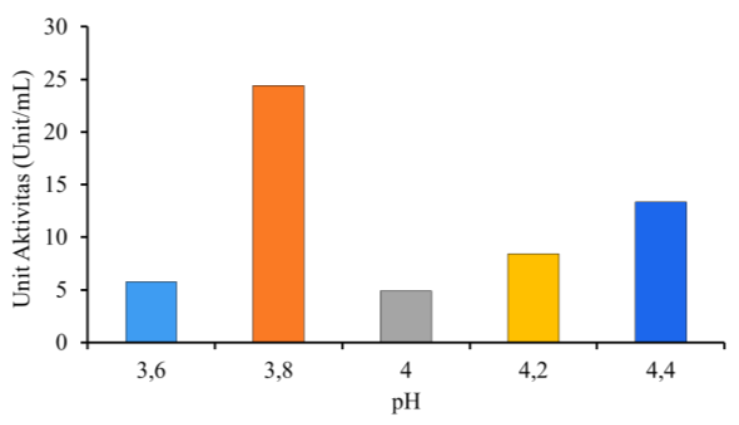

Gambar 2. Grafik pH optimum

Gambar 2 menunjukkan bahwa aktivitas kitinase mengalami peningkatan sampai $\mathrm{pH} 3,8$ ( $\mathrm{pH}$ optimum) dengan unit aktivitas sebesar 24,44 Unit/mL kemudian menurun pada $\mathrm{pH} 4$ dan kembali mengalami peningkatan pada $\mathrm{pH}$ 4,2 dan 4,4.

\section{Karakterisasi Suhu Optimum Kitinase}

Berdasarkan pertumbuhannya mikroba digolongkan menjadi lima kelompok, yaitu psikrofil tumbuh pada suhu $-5-20^{\circ} \mathrm{C}$, mesofil suhu $20-45^{\circ} \mathrm{C}$, termofil $45-65^{\circ} \mathrm{C}$, termofil ekstrim $65-85^{\circ} \mathrm{C}$ dan hipertermofil $85-100^{\circ} \mathrm{C}$. Dalam reaksi enzimatis, suhu berperan dalam meningkatkan reaksi antara substrat dengan enzim. Aktivitas kitinase mengalami peningkatan pada suhu $40,5^{\circ} \mathrm{C}$ (suhu optimum) dengan unit aktivitas sebesar 57,77 Unit/mL.

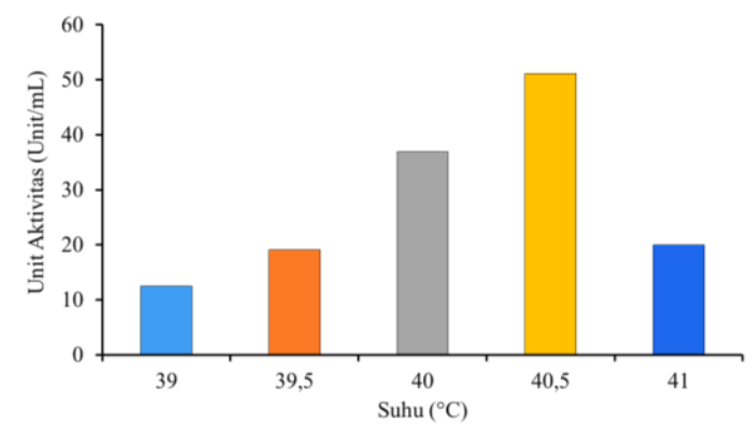

Gambar 3. Grafik suhu optimum

Aktivitas enzim pada suhu $39^{\circ} \mathrm{C}$ rendah disebabkan tidak semua substrat berikatan dengan sisi aktif enzim. Saat suhu meningkat sampai suhu optimum yaitu $40,5^{\circ} \mathrm{C}$, kecepatan reaksi enzim naik karena energi kinetik bertambah. Hal ini memperbesar peluang enzim dan substrat bereaksi untuk menghasilkan produk yang maksimal. Pada suhu $41^{\circ} \mathrm{C}$ aktivitas enzim menurun. Menurunnya aktivitas mengikuti meningkatnya suhu di atas optimum biasanya disebabkan oleh perusakan enzim [11].

Adanya perubahan suhu juga akan memperngaruhi ikatan hidrogen atau interaksi hidrofobik yang berperan dalam menjaga konformasi molekul enzim [13]. Perubahan konformasi akan mempengaruhi sisi aktif dari enzim, kondisi panas tertentu menyebabkan ikatan hidrogen tersebut akan putus. Putusnya satu ikatan hidrogen akan menyebabkan mudahnya pemutusan ikatan hidrogen selanjutnya dalam rantai polipeptida 
tersebut, sehingga protein enzim mengalami denaturasi.

\section{Kesimpulan}

Hasil penelitian menunjukkan bahwa kitinase dapat diperoleh dari isolat jamur akuatik kitinolitik yang berasal dari kupu-kupu dengan menggunakan substrat koloidal kitin. Aktivitas spesifik tertinggi kitinase yang diperoleh dari jamur akuatik kitinolitik berasal dari kupu-kupu adalah 51,17 Unit/mg protein pada fraksi 3. Kondisi optimum kerja kitinase dari jamur akuatik kitinolitik dicapai pada $\mathrm{pH} 3,8$ dan suhu $40,5^{\circ} \mathrm{C}$.

\section{Daftar Pustaka}

[1] Nuniek Herdyastuti, Tri Joko Raharjo, Mudasir Mudasir, Sabirin Matsjeh, Chitinase and chitinolytic microorganism: Isolation, characterization and potential, Indonesian Journal of Chemistry, 9, 1, (2010) 37-47 http://dx.doi.org/10.22146/ijc.457

[2] Maria Swiontek Brzezinska, Elżbieta Lalke-porczyk, Wojciech Donderski, The role of chitinolytic bacteria and fungi in biodegradation of crustacean remains in lacustrine habitats, Pol. J. Ecol, 56, 2, (2008) 335342

[3] Hazel Davies, Carol A Butler, Do butterflies bite?: Fascinating answers to questions about butterflies and moths, Rutgers University Press, 2008.

[4] Mitsuhiro Veda, Motoo Arai, Purification and some properties of chitinases from Aeromonas sp. No. 10S-24, Bioscience, biotechnology, and biochemistry, 56, $\quad 3, \quad$ (1992) $460-464$ http://dx.doi.org/10.1271/bbb.56.460

[5] Dian Rachmadani, Mempelajari pemurnian enzim kitosanase termostabil dari isolat Bacillus licheniformis MB-2 asal Tompaso, Manado, Sulawesi Utara, Jurusan Teknologi Pangan, IPB, Bogor

[6] Maggy T Suhartono, Enzim dan bioteknologi, PAU Bioteknologi IPB, Bogor, (1989)

[7] Nico Dynnar, Pemurnian dan karakterisasi enzim katepsin dari ikan bandeng (Chanos chanos Forskall), Jurusan Teknologi Produk Perairan, IPB, Bogor

[8] IPD Arjito, Analisis protein jaringan otak sapi dengan metode isolasi, purifikasi dan visualisasi, Jurnal GaneÇ Swara, 3, 2, (2009) 55-58

[9] Andestian Wijaya, Pengembangan Teknologi Papan Komposit Dari Limbah Batang Pisang (Musa Sp.): Sifat Fisis Dan Mekanis Papan Pada Berbagai Tingkat Asetilasi, Fakultas Kehutanan, IPB, Bogor

[10] Oliver H Lowry, Nira J Rosebrough, A Lewis Farr, Rose J Randall, Protein measurement with the Folin phenol reagent, The Journal of biological chemistry, 193, 1, (1951) 265-275

[11] Wesley A. Volk, Margaret F. Wheeler, Mikrobiologi Dasar, Markham, Erlangga, Jakarta, 1993.

[12] Trevor Palmer, Understanding enzymes, 4 ed., Prentice Hall/Ellis Horwood, 1995.

[13] Rudy Wijaya, Karakteristik Enzim serupa Tripsin dari Cacing Tanah, Teknologi Pertanian, IPB, Bogor 